U.S. Department of the Interior

U.S. Geological Survey

\title{
Volcano Hazards in the Mount Adams Region, Washington
}

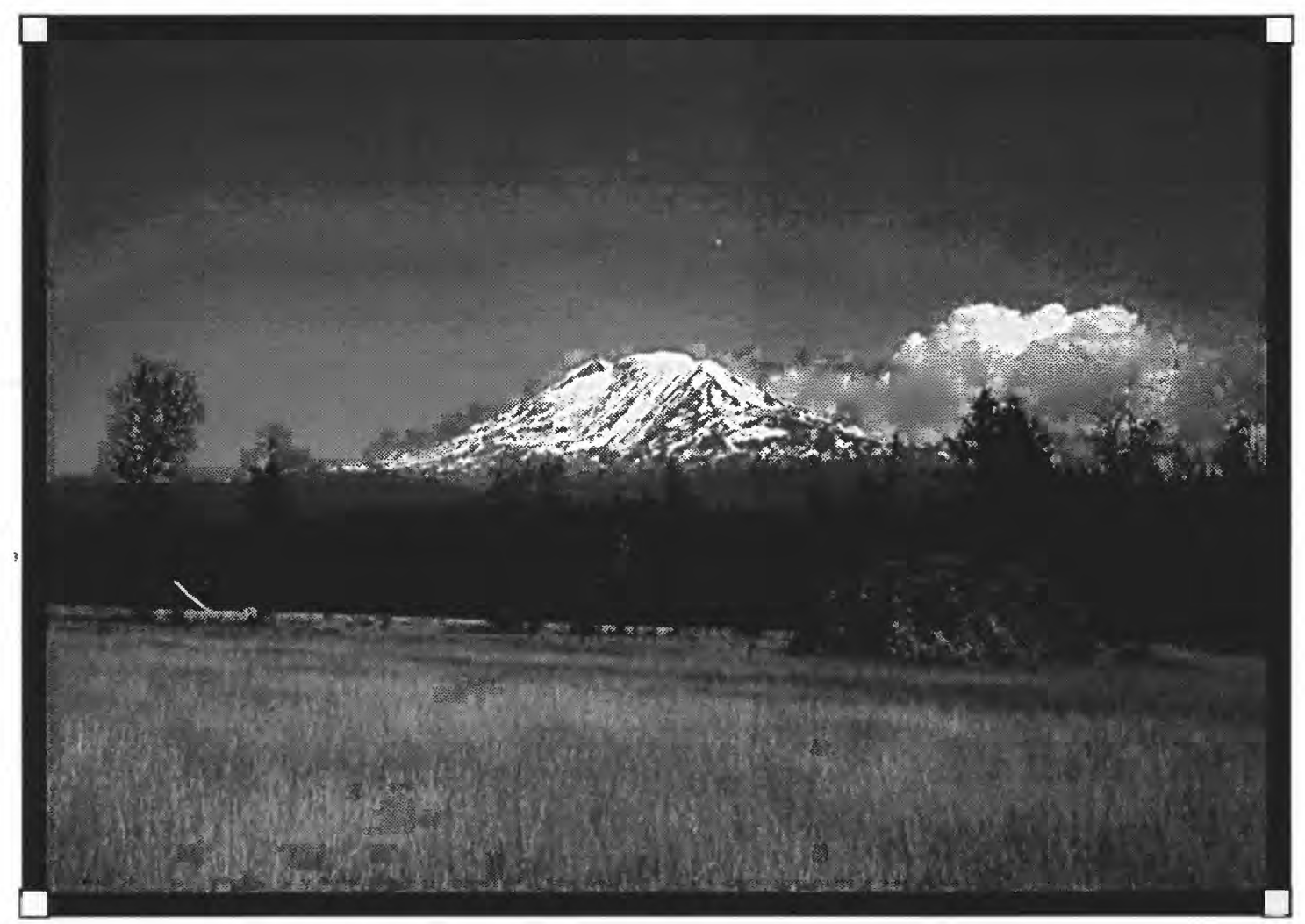

By

William E. Scott ${ }^{1}$, Richard M. Iverson ${ }^{1}$, James W. Vallance ${ }^{2}$, and Wes Hildreth ${ }^{3}$

1. U.S. Geological Survey, David A. Johnston Cascades Volcano Observatory, 5400 MacArthur Blvd., Vancouver WA 98661

2. Department of Civil Enginering and Applied Mechanics, McGill University, Montreal, Canada 43A $2 K 6$

3. U.S. Geological Survey, 345 Middlefield Rd., Menlo Park CA 94025

\section{Open-File Report 95-492}

This report is preliminary and has not been reveiwed for conformity with U.S. Geological Survey editorial standards. Any use of trade, product or firm names is for descriptive purposes only and does not imply endorsement by the U.S. Government. 


\section{CONTENTS}

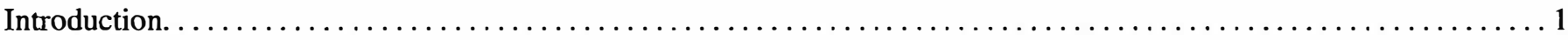

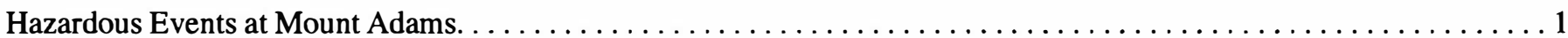

Lava flows are the most likely type of future eruptive event. $\ldots \ldots \ldots \ldots \ldots \ldots \ldots \ldots \ldots \ldots \ldots \ldots \ldots \ldots \ldots$

Lava flows can melt snow and ice and cause pyroclastic flows, lahars, and floods. . . . . . . . . . . . . 2

Even minor tephra falls can be disruptive and hazardous. . . . . . . . . . . . . . . . . . . 2

Landslides and lahars not necessarily related to eruptions pose the most serious threat. $\ldots \ldots \ldots \ldots \ldots \ldots \ldots 2$

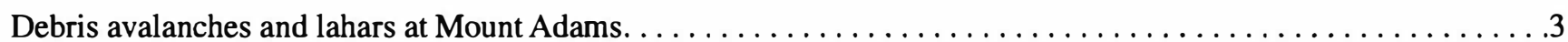

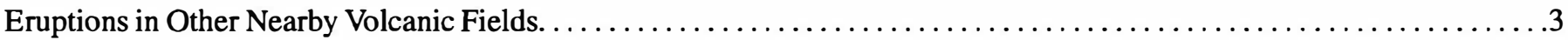

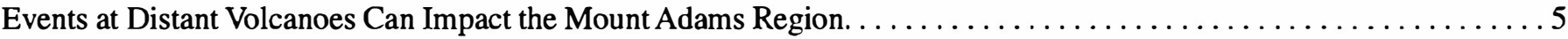

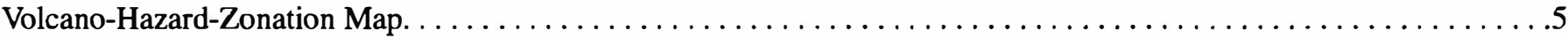

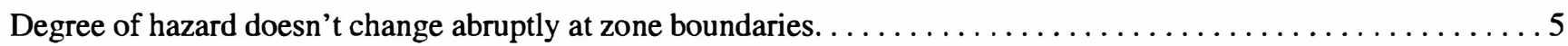

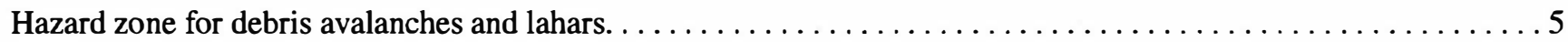

Hazard zones for lava flows. . . . . . . . . . . . . . . . . . . . .

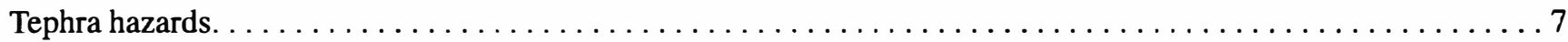

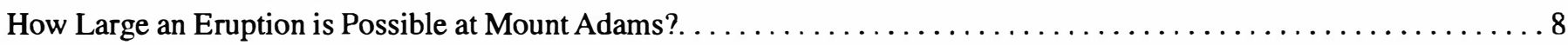

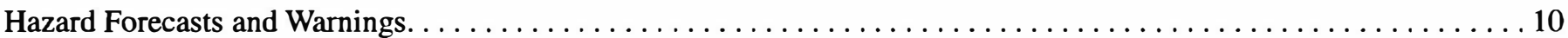

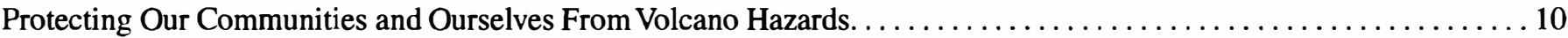

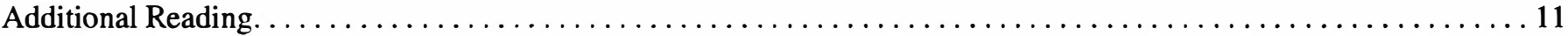

\section{TABLE}

1. Summary of eruption rates and coverage by lava flows that determine lava-flow hazard

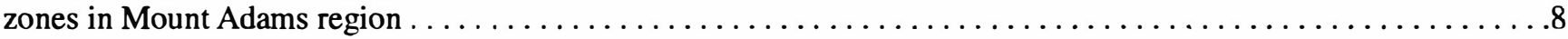

\section{FIGURES}

1. Notable geologic events in the Mount Adams region during the past 15,000 years $\ldots \ldots \ldots \ldots \ldots \ldots \ldots \ldots$

2a. Annual probability of $1 \mathrm{~cm}$ or more of tephra accumulation in Washington and

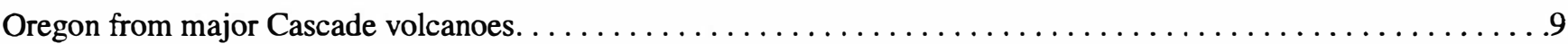

2b. Annual probability of $10 \mathrm{~cm}$ or more of tephra accumulation in Washington and

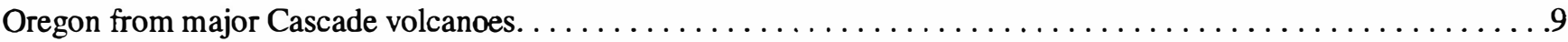

\section{PLATES [in pocket]}

1. Map of south-central Washington showing young volcanoes, lava-flow hazard zones, and lateral-blast hazard zone for Mount Adams.

2. Volcano-hazard-zonation map of Mount Adams.

Cover photo: Mount Adams from the Trout Lake lowland. Flat surface and large boulder were deposited by a large lahar about 6,000 years ago. (Photo by J. W. Vallance). 


\title{
Volcano Hazards in the Mount Adams Region, Washington
}

\author{
By William E. Scott, Richard M. Iverson, James W. Vallance, and Wes Hildreth
}

\section{INTRODUCTION}

Mount Adams, one of the largest volcanoes in the Cascade Range, dominates the Mount Adams volcanic field in Skamania, Yakima, Klickitat, and Lewis counties and the Yakima Indian Reservation of south-central Washington. The nearby Indian Heaven and Simcoe Mountains volcanic fields lie west and southeast, respectively, of the $1250-\mathrm{km}^{2}\left(500-\mathrm{mi}^{2}\right.$ ) Adams field (plate1). Even though Mount Adams has been less active during the past few thousand years than neighboring Mounts St. Helens, Rainier, and Hood, it assuredly will erupt again. Future eruptions will probably occur more frequently from vents on the summit and upper flanks of Mount Adams than from vents scattered in the volcanic fields beyond. Large landslides and lahars that need not be related to eruptions probably pose the most destructive, far-reaching hazard of Mount Adams. The purpose of these maps and booklet is to (1) describe the kinds of hazardous geologic events that will likely occur in the future at Mount Adams and at other volcanoes in the region, (2) outline the areas that will most likely be affected by these events, and (3) recommend actions that individuals and government agencies can take to protect lives and property.

\section{HAZARDOUS EVENTS AT MOUNT ADAMS}

Volcanoes pose a variety of geologic hazards -both during eruptions and in the absence of eruptive activity. During much of its history, Mount Adams has displayed a relatively limited range of eruptive styles. Highly explosive eruptions have been rare. Compared to the tens of large explosive eruptions at nearby Mount St. Helens during the past 20,000 years, eruptions of Mount Adams have been meek. Eruptions at Mount St. Helens have blanketed areas more than $200 \mathrm{~km}$ (120 mi) downwind with ash deposits several centimeters or inches thick, but those at Mount Adams have blanketed only areas a few kilometers away with a similar thickness of ash. Nonetheless, despite their low level of explosivity, eruptions at Mount Adams are hazardous. More importantly, even during times of no eruptive activity, landslides of weakened rock that originate on the steep upper flanks of Mount Adams can spawn lahars, which are watery flows of volcanic rocks and mud that surge downstream like rapidly flowing concrete. Lahars -- also known as mudflows or debris flows -- can devastate valley floors tens of kilometers from the volcano.

\section{Lava flows are the most likely type of future eruptive event}

The dominant type of eruption at Mount Adams, as well as in the adjacent volcanic fields, produces lava flows, or streams of molten rock. Plate 1 shows lava flows that have occurred in the region during the past 10,000 years: eight flows issued from vents on Mount Adams and covered an area of about $50 \mathrm{~km}^{2}$ $\left(20 \mathrm{mi}^{2}\right)$; one large lava flow erupted in the Indian Heaven volcanic field about $30 \mathrm{~km}(20 \mathrm{mi})$ southwest of Mount Adams and covered a similar-sized area; another flow erupted from a vent about $25 \mathrm{~km}(15 \mathrm{mi})$ west of Indian Heaven and covered about $10 \mathrm{~km}^{2}(4$ $\mathrm{mi}^{2}$ ).

These and older lava flows typically travelled less than $20 \mathrm{~km}(12 \mathrm{mi})$ from vents, but in rare cases more voluminous flows reached lengths of 25 to almost 50 $\mathrm{km}(15$ to $30 \mathrm{mi})$. Typical lava flows on the lower flanks of Mount Adams and elsewhere in the volcanic fields spread onto gentle slopes and funnelled into valleys. The moving flows were several meters (tens of feet) to more than $30 \mathrm{~m}(100 \mathrm{ft})$ thick and consisted of crusty lava blocks enclosing a more fluid, molten core. Their steep fronts advanced quite slowly--at

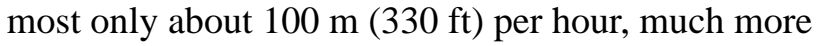
slowly than people typically walk. Even so, lava 
flows can bury, crush, or burn all structures in their paths, and hot lava boulders cascading off flow margins can endanger spectators and start forest fires. A typical eruption consists of extrusion of a single lava flow over a period of days or weeks or of a sequence of several flows erupted over weeks to a few years. Intermittent eruptions over years to decades might build a broad apron of lava flows on a flank of Mount Adams or even build a separate small volcano several hundred meters high ( $300 \mathrm{~m}$ equals $1,000 \mathrm{ft}$ ) and 10 $\mathrm{km}(6 \mathrm{mi})$ or more in diameter.

Explosions and gases streaming from the lavaflow vents can hurl upward fragments of rock and lava that range in size from large blocks to fine dust. Such material is called tephra by volcanologists. The coarser particles fall to the ground around the vent and form a deposit that ranges from a blanket less than 1 meter ( $3 \mathrm{ft}$ ) thick to a pile, called a cinder cone, more

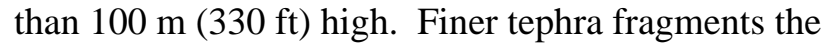
size of sand and silt grains, called ash, can be carried downwind and form deposits that thinly mantle areas tens to hundreds of kilometers away.

More violent eruptions can occur from vents beneath lakes or in areas with high water tables as magma interacts explosively with water. The explosions can propel large rock fragments several kilometers and generate pyroclastic flows--flows of hot rocks, ash, and gases, which can move rapidly outward more than $10 \mathrm{~km}(6 \mathrm{mi})$.

\section{Lava flows can melt snow and ice and cause pyroclastic flows, lahars, and floods}

Lava flows extruded on snow or ice-covered terrain can generate sufficient meltwater to cause small lahars and floods. More dangerous, however, is extrusion on terrain so steep or icy that the lava flow breaks apart and produces avalanches of hot lava fragments. Such avalanches from near the summit of Mount Adams can form pyroclastic flows that may travel downslope as far as $15 \mathrm{~km}(9 \mathrm{mi})$. Pyroclastic flows can erode and melt large quantities of ice and snow, transform into lahars, or produce water floods. These lahars or floods can then travel tens of kilometers farther down valleys. Pyroclastic flows formed by avalanches from hot lava flows have been rarer at Mount Adams during the past 10,000 years than at Mount Hood and other nearby volcanoes.

\section{Even minor tephra falls can be disruptive and hazardous}

Small explosions that accompanied past lava-flow eruptions at Mount Adams and other volcanoes in the region were strong enough to hurl lava blocks from vents, and probably created clouds of tephra that rose thousands of meters into the atmosphere. In depositing only a few millimeters of tephra for tens or, rarely, a few hundred kilometers downwind, such clouds offer little threat to life or structures. But tephra clouds can create tens of minutes to hours of darkness as they pass over a downwind area, even on sunny days, and reduce visibility on highways. Deposits of tephra can short-circuit electric transformers and power lines, especially if the tephra is wet, which makes it highly conductive, sticky, and heavy. Tephra injested by vehicle engines can clog filters and increase wear. Tephra clouds often generate lightning that can interfere with electrical and communication systems and start fires. Finally, and perhaps most importantly, even small, dilute tephra clouds pose a significant hazard to aircraft that fly into them. As explained below, other volcanoes, especially Mount St. Helens, do produce large explosive eruptions, and these volcanoes pose the greatest threat of significant tephra fall in the region.

The lessons learned in Washington communities such as Yakima, Ritzville, and Spokane during the 1980 eruption of Mount St. Helens are used throughout the Pacific Northwest and elsewhere in the world to prepare governments, businesses, and citizens for future tephra falls. All three communities experienced significant disruptions in transportation, business activity, and community services during fallout of from 0.5 to $8 \mathrm{~cm}$ ( $1 / 4$ to 3 in) of tephra and for several days after the eruption. The greater the amount of tephra that fell, the longer a community took to recover. As perceived by residents, tephra falls of less than $0.5 \mathrm{~cm}(1 / 4 \mathrm{in})$ were a major inconvenience, whereas falls of more than $1.5 \mathrm{~cm}(2 / 3 \mathrm{in})$ constituted a disaster. Nonetheless, all three communities recovered to nearly normal activities within two weeks.

\section{Landslides and lahars not necessarily related to eruptions pose the most serious threat}

Mount Adams has erupted little during the past 10,000 years, but most of the present volcanic cone was formed during a preceding 30,000-year period of 
rapid, eruptive growth. During and since its formation, much of the upper part of the cone has been eroded by glaciers to form steep, unstable slopes. Ground water warmed by residual heat and acidified by volcanic gases has circulated through porous zones and weakened the rocks that compose roughly two cubic kilometers (one-half cubic mile) of Mount Adams' summit by altering parts of the rocks to mud. These steep, weakened areas are prone to failures that spawn rapidly moving landslides called debris avalanches. Debris avalanches can attain speeds that exceed $160 \mathrm{~km} / \mathrm{hr}(100 \mathrm{mi} / \mathrm{hr})$, and the largest avalanches can sweep down valleys more than $50 \mathrm{~km}$ (30 $\mathrm{mi})$ before stopping. Moreover, debris avalanches that contain enough water and mud can transform into lahars that flow down valleys many tens of kilometers farther at speeds up to $50 \mathrm{~km} / \mathrm{hr}(30 \mathrm{mi} / \mathrm{hr})$. Debris avalanches and lahars can smash or bury houses and bridges, and can choke river valleys with sediments. Debris avalanches and lahars may be triggered by magma intrusion, eruptions, steam explosions, earthquakes, or intense rainstorms, but others have no apparent trigger and may result from gradual weakening of rock masses that finally become unstable enough to fail.

\section{Debris avalanches and lahars at Mount Adams}

During the past 10,000 years, the steep upper slopes of Mount Adams have produced several notable debris avalanches (figure 1). In 1921, about 4 million cubic meters (5 million cubic yards) of altered rock fell from the head of Avalanche Glacier on the southwest flank of the volcano and travelled almost $6 \mathrm{~km} \mathrm{(4}$ mi) down Salt Creek valley. The debris avalanche contained or acquired sufficient water to partly transform into small lahars. Ancient debris avalanches of much larger size have also occurred at Mount Adams, and these formed lahars that travelled far down the White Salmon and other valleys. An avalanche of roughly 70 million cubic meters $(90$ million cubic yards) of debris initiated the largest of these lahars about 6000 years ago. This lahar inundated the Trout Lake lowland and continued down the valley of the White Salmon River at least as far as Husum, more than $55 \mathrm{~km}$ (35 mi) from Mount Adams. The lahar deposit left in the lowland varies from 1 to $20 \mathrm{~m} \mathrm{(3} \mathrm{to}$ $65 \mathrm{ft}$ ) thick; it is clearly visible today as a sediment layer in the banks of the White Salmon River and as isolated blocks (some more than $5 \mathrm{~m}(16 \mathrm{ft}$ ) in diameter) that protrude from fields and meadows (see cover photograph).

No geologic evidence links Mount Adams' debris avalanches and lahars to eruptive activity. Therefore, these extremely hazardous events can occur without nature's warnings that typically signal the onset of volcanic unrest. However, the onset of volcanic unrest, with its earthquakes and steam explosions, unquestionably increases the likelihood of debris avalanches and enhances the probability of a catastrophic event that would have serious consequences in areas far downstream from the volcano.

Lahars caused by eruptions or by debris avalanches also affect downstream areas by filling stream channels with sediment and by providing a source of easily eroded sediment. Examples from many volcanoes, including nearby Mount St. Helens, show that these effects can persist for years or decades. Channels become unstable and can shift rapidly. Channel capacity shrinks and flooding increases. Streams that drain the north and northwest flanks of Mount Adams can discharge sediment from lahars into Swift Reservoir on the Lewis River and Riffe Lake on the Cowlitz. Streams that drain the southwest and east flanks can deliver sediment to the Columbia River and could affect navigation and hydroelectric operations at Bonneville Dam. Impacts on the small reservoir and hydroelectric operation on the White Salmon River could be severe.

\section{ERUPTIONS IN OTHER NEARBY VOLCANIC FIELDS}

During the past one million years, numerous volcanic vents were active throughout south-central Washington, from Vancouver to Goldendale (plate 1). Most were probably active for relatively short times ranging from days to tens of years. Unlike Mount Adams, which has erupted repeatedly for hundreds of thousands of years, these vents typically did not erupt more than once. Rather, each erupting vent built a separate, small volcano, and over time a field of numerous overlapping volcanoes was created. Clusters of these vents define the Mount Adams, Indian Heaven, and Simcoe Mountains volcanic fields. In addition, the Goat Rocks volcanic center lies $30 \mathrm{~km}$ (18 mi) north of Mount Adams. The Mount Adams and Indian Heaven fields have been the most active recently; the Simcoe field and the Goat Rocks center have not erupted for hundreds of thousands of years. 


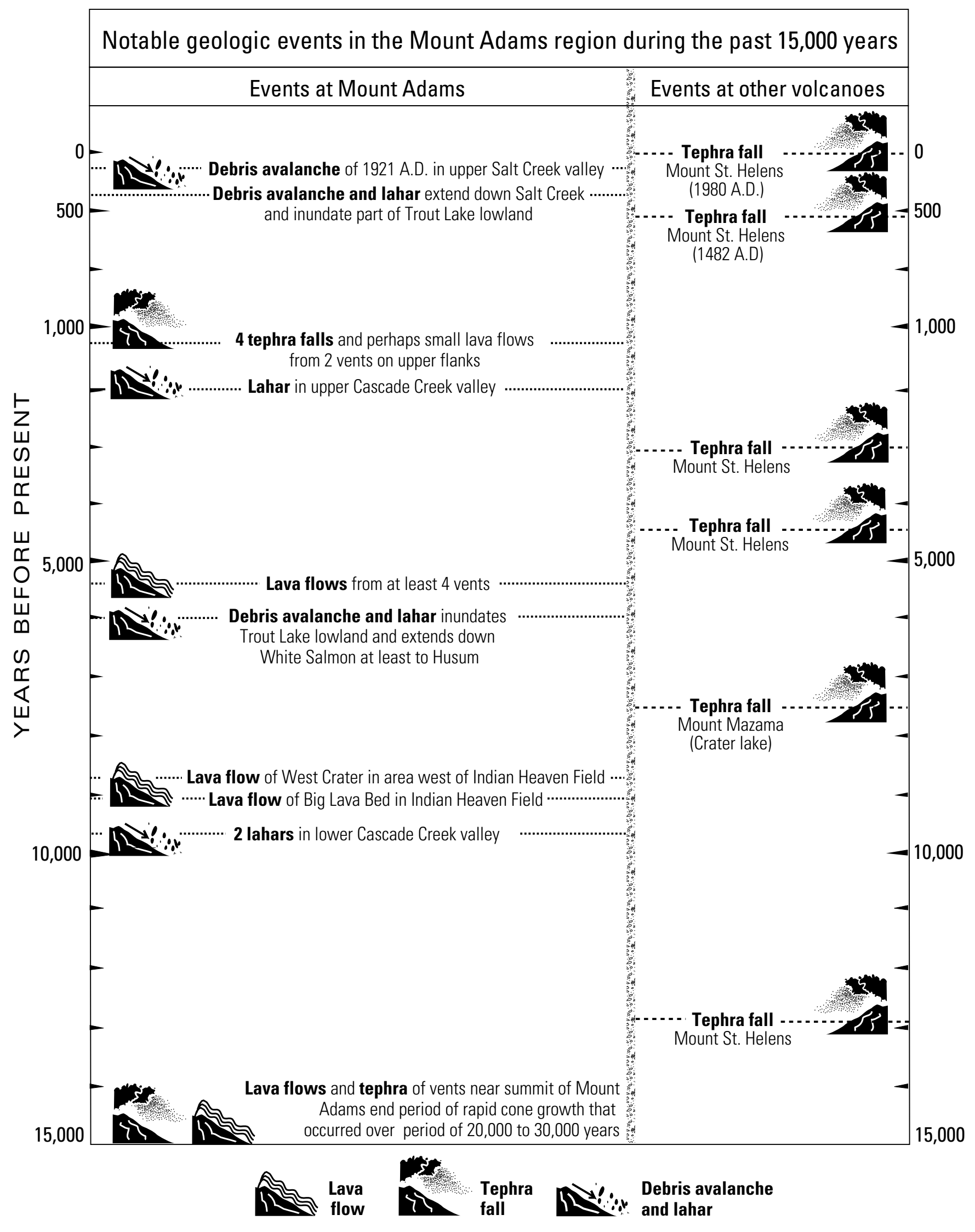

Figure 1. Notable geologic events in the Mount Adams region during the past 15,000 years. Mount Adams lava flows and tephra falls are not precisely dated. Their ages are bracketed largely by tephra falls from other volcanoes. 
Because the numerous volcanoes in these fields were active for geologically brief times, they are much smaller than Mount Adams. Underwood Mountain, which lies west of the mouth of the White Salmon River, is one such volcano. It is about $8 \mathrm{~km}(5 \mathrm{mi})$ in diameter and less than $800 \mathrm{~m}(2,600 \mathrm{ft})$ high. About 9,000 years ago, the Big Lava Bed (plate 1) issued from a small volcano less than $300 \mathrm{~m}(1,000 \mathrm{ft})$ high and partly filled the northwest part of the Little White Salmon River drainage basin with a thick lava flow almost $16 \mathrm{~km}(10 \mathrm{mi})$ long. A few ancient lava flows were sufficiently large to flow down tributary valleys, spread out on the floor of the Columbia River Gorge, and dam the river to form a lake. The river then cut a new channel around or through the lava flow.

\section{EVENTS AT DISTANT VOLCANOES CAN IMPACT THE MOUNT ADAMS REGION}

Mount Adams and nearby vents are not the only sources of volcano hazards in the region. For example, volcanic ash produced by explosive eruptions at Mount St. Helens $(50 \mathrm{~km}$ or $30 \mathrm{mi}$ to the west of Mount Adams) and Mount Mazama (site of Crater Lake, $370 \mathrm{~km}$ or $230 \mathrm{mi}$ to the south) form the thickest and most conspicuous ash layers of the past 15,000 years around Mount Adams. Ash of the Mazama eruption is 2 to $8 \mathrm{~cm}$ ( 1 to 3 in) thick, while ash of several St. Helens' eruptions ranges from a fraction of a centimeter to $40 \mathrm{~cm}$ (16 in) thick.

Lahars generated at Mounts St. Helens and Rainier have inundated the lower reaches of the Lewis and Cowlitz Rivers, which also drain Mount Adams. Even a lahar from Mount Hood that flowed down Hood River inundated the lower White Salmon River. It was generated by a large debris avalanche that crossed the Columbia River and flowed a few miles up the lower White Salmon drainage.

\section{VOLCANO-HAZARD-ZONATION MAP}

The accompanying map (plate 2) shows areas that could be affected by future debris avalanches and lahars, as well as by eruptions. Hazard zones are based largely on the type and scale of events that have occurred in the recent geologic past at Mount Adams and in the surrounding volcanic fields. The zonation for debris avalanches and lahars also takes into account the distribution and volume of weakened, altered rock on Mount Adams' summit and upper flanks, which could spawn events much larger than those of the recent past. Hazard zonation for tephra falls is based chiefly on contributions of tephra from other major Cascade volcanoes, especially Mount St. Helens.

\section{Degree of hazard doesn't change abruptly at zone boundaries}

Although we show boundaries of hazard zones for lava flows, debris avalanches, and lahars by lines or edges of patterns, the degree of hazard does not change abruptly at these boundaries. Rather, the hazard decreases gradually as distances from the volcano increase and as elevations above valley floors increase. Areas immediately beyond outer hazard zones should not be regarded as hazard-free, because the boundaries can only be approximately located, especially in areas of low relief. Too many uncertainties exist about the source, size, and mobility of future events to locate zero-hazard zones with confidence.

\section{Hazard zone for debris avalanches and lahars}

Masses of altered and weakened rock on the steep upper part of Mount Adams can collapse and form debris avalanches, which can transform into lahars that flow far down valleys. These masses of weak rock occur widely in the summit area, but are most prone to failure on the southwest and east flanks owing to deep erosion and steep slopes. Debris avalanches and lahars originating in these areas would descend tributaries of the White Salmon or Klickitat Rivers. Debris avalanches from areas of weakened rock on the northwest and northeast flanks would enter tributaries of the Lewis, Cispus, and West Fork Klickitat Rivers. However, the lack of deep valleys on these flanks would allow avalanches to spread laterally, and spreading would probably lessen the magnitude of flows in downstream areas because much debris would be deposited on the volcano's flanks.

The map designates the zone of hazard from debris avalanches and lahars as hazard zone DL. Zone DL includes areas that could be inundated as a result of collapse of $1 \mathrm{~km}^{3}\left(1 / 4 \mathrm{mi}^{3}\right)$ of weak rock, snow, and ice near Mount Adams' summit. A $1-\mathrm{km}^{3}$ debris avalanche is about half the size of the avalanche that removed the summit and north flank of 
Mount St. Helens during its catastrophic 1980 eruption and about half the size of the largest avalanche that has occurred in the decipherable geologic past at Mount Rainier. At Mount Adams, an avalanche of roughly $1 \mathrm{~km}^{3}$ is the largest deemed plausible without conspicuous precursors. Debris avalanches larger than $1 \mathrm{~km}^{3}$ could occur at Mount Adams, but they would probably require intrusion of magma that generates earthquakes and deforms the volcano for a week or more, and this activity would be detected by monitoring equipment. An avalanche as large as $1 \mathrm{~km}^{3}$ would almost certainly be funnelled into tributaries that join to form one or perhaps two major river valleys. Simultaneously, it would likely transform into a lahar.

Zone DL shows projections of areas in all valleys that could be inundated by the combination of a $1-\mathrm{km}^{3}$ avalanche and lahar. Projections for the upper volcano flanks assume that the debris avalanche has downslope and lateral mobilities similar to those of comparable avalanches elsewhere. Projections for downstream areas (below about $1000 \mathrm{~m}$ or $3300 \mathrm{ft}$ elevation) assume that the avalanche transforms completely into a lahar, which subsequently maintains a constant volume and flows in a manner similar to that of large historic and prehistoric lahars at Mounts Rainier and St. Helens. Smaller lahars formed by smaller debris avalanches or by melting of snow and ice during eruptions would affect only part of zone DL. However, repeated eruptions near Mount Adams' summit occurring over a period of months to years could spawn numerous small lahars that together might inundate a substantial fraction of zone DL, especially as stream channels become clogged with sediment.

A large avalanche-triggered lahar in the White Salmon drainage could bury the Trout Lake lowland, enter the Columbia River, and inundate both the Oregon and Washington shorelines for a considerable distance. A lahar comprising $1 \mathrm{~km}^{3}$ of debris would likely transport enough sediment to the Columbia to exceed the $0.7 \mathrm{~km}^{3}$ capacity $\left(0.14 \mathrm{~km}^{3}\right.$ usable storage) of Bonneville Reservoir and cause overtopping of Bonneville dam. Consequences of dam overtopping, which might trigger dam failure, could be severe. A large lahar could itself dam the Columbia River, back water up behind it, and fail, with similarly severe results.

The steep upper east flank of Mount Adams drains into the Klickitat River through several broad tributary valleys. As recently as 1988 two small lahars in one of these tributaries, Big Muddy Creek, buried streamside structures used to divert irrigation water. Down- stream, the Klickitat flows in a narrow, winding canyon for more than $100 \mathrm{~km}(60 \mathrm{mi})$ and enters the Columbia River at Lyle. The first of several small settlements along the canyon floor lies about $60 \mathrm{~km}(40$ mi) from the volcano. Hazard zone DL covers the floor and lower slopes of the canyon to the Klickitat's mouth and encompasses these settlements. A large lahar in the Klickitat valley could affect the Columbia River, Bonneville Reservoir, and Bonneville Dam in a manner similar to a large lahar in the White Salmon valley.

The debris avalanche and lahar hazard zone DL covers broad areas of the north and west flanks of Mount Adams in the headwaters of the Cispus and Lewis Rivers because the lack of well-defined valleys in these areas would allow debris avalanches and lahars to spread laterally. Development along the Cispus and Lewis Rivers, other than forest roads and a few campgrounds, occurs more than $50 \mathrm{~km}(30 \mathrm{mi})$ downstream from the volcano, and both rivers flow into large reservoirs (Riffe Lake, usable storage 1.6 $\mathrm{km}^{3}$, and Swift Reservoir, usable storage $0.5 \mathrm{~km}^{3}$, respectively) before there is a substantial population at risk. Entry of a large lahar would reduce the capacity of these reservoirs, cause shoreline inundation, and possibly affect dam stability. Lowering of reservoir levels to make all or part of the usable storage available would permit containment of most lahars.

To provide perspective on the magnitude and frequency of debris avalanches and lahars at Mount Adams, the map depicts the path of the Trout Lake avalanche and lahar (TL), which occurred in the upper White Salmon River drainage about 6000 years ago. This is the only debris avalanche or lahar that has travelled far beyond the volcano flanks in the past 10,000 years. The lahar involved about 70 million cubic meters (90 million cubic yards) of debris, inundated much of the Trout Lake lowland, and flowed at least as far as Husum, about $55 \mathrm{~km}$ (35 mi) from the volcano. The Trout Lake avalanche and lahar (TL) therefore provides a gage of the extent of lahars that are roughly 10 times smaller but considerably more probable than a great lahar that could inundate an entire valley in hazard zone DL.

On the basis of frequency and magnitude of past events at Mount Adams (figure 1) and comparison with events at similar volcanoes, we can roughly estimate the annual probability (chance of occurrence) of debris avalanches and lahars inundating some part of hazard zone DL. Small avalanches or lahars triggered by rainfall, rapid snow melt, heavy snow fall, or glacier outbursts occur frequently, but seldom travel 
more than several kilometers from their sources on steep volcano flanks. Such events have annual probabilities greater than 1 in 10; they endanger backcountry recreationists and may damage timber, trails and bridges, but not settled areas. Lahars large enough to reach the Trout Lake lowland and affect communities have annual probabilities of about 1 in 100 to 1 in 1,000. A lahar the size of the Trout Lake lahar (TL) has an annual probability of about 1 in 1,000 to 1 in 10,000 , whereas a lahar of sufficient magnitude to inundate zone DL along the length of one or more valleys has not occurred in the last 10,000 years and has an annual probability less than 1 in 10,000.

\section{Hazard zones for lava flows}

Eruptions of Mount Adams and other volcanoes in the surrounding volcanic fields are dominated by lava flows. Explosions preceding or accompanying such eruptions also hurl rock fragments outward and eject clouds of ash into the atmosphere; some especially violent explosions can also generate pyroclastic flows. Lava flows can melt snow and ice to form lahars, as can pyroclastic flows generated by landsliding of hot lava flows on steep, ice-covered slopes. Effects of such events are restricted largely to areas within about $15 \mathrm{~km}(8 \mathrm{mi})$ of the erupting vent, except for some lahars that can affect areas along river valleys tens of kilometers away.

The Mount Adams region is divided into three hazard zones on the basis of several measures of the rate of past eruptive activity (table 1; plates 1 and 2). One way of comparing eruptive activity is to divide the lava volume erupted per unit time by the area of a lava field to obtain an average burial rate. Even though successive lava flows bury areas in a very irregular pattern, average burial rates provide useful comparisons. The area having the greatest burial rate is the focal area of the Mount Adams volcanic field, which lies on the upper flanks of Mount Adams. It also has had the largest number of active vents during the past 10,000 years. Areas that lie in low areas within $15 \mathrm{~km}(9 \mathrm{mi})$ downslope of the focal vent area outlined on the map are designated as lava-flow hazard zone LA. Zone LB includes (1) areas at the north and south ends of the Mount Adams volcanic field, which have lower burial rates than the focal area and have had no eruptions in the past 10,000 years, (2) ridges that stand well above zone LA close to Mount Adams, and (3) the Indian Heaven volcanic field, which has a low burial rate, but which has had a large lava flow in the past 10,000 years. Zone LC includes areas of widely scattered vents around the Mount Adams and Indian Heaven fields, the younger part of the Simcoe Mountains field northwest of Goldendale, and areas that extend north toward Goat Rocks. These areas have much lower burial rates than areas in zones LA and LB.

On the basis of past activity, we infer that the probability of future eruptions decreases between successive lava-flow-hazard zones by a factor of about 5 to 10 . We estimate that the annual probability of an eruption occurring in zone LA is about 1 in 1,000 . But because such a lava eruption would likely only cover one to a few percent of zone LA, the annual probability of a given point in LA being covered by a lava flow is probably about 1 in 30,000 to 1 in 100,000 . Likewise, the annual probability of lava flows covering a given point in zone LB probably ranges from 1 in 100,000 to 1 in 1,000,000; for zone $\mathrm{LC}$, it is less than 1 in $1,000,000$. Compared with other geologic hazards such as debris avalanches and lahars, the probability of lava flows significantly affecting the region is small. Once precursory activity or a lava-flow eruption begins, scientists can better define areas likely to be affected.

\section{Tephra hazards}

Even minor tephra eruptions can disrupt daily life and commerce and greatly endanger aircraft. The most serious tephra hazards in the region are due to the proximity of Mount St. Helens, the most prolific producer of tephra in the Cascades during the past few thousand years. The accompanying maps (figure 2) provide estimates of the annual probability of tephra fall affecting the region. The maps are based on the combined likelihood of tephra-producing eruptions occurring at Cascade volcanoes, the relationship between thickness of a tephra-fall deposit and distance from its source vent, and regional wind patterns. Probability zones extend farther east of the range because winds blow from westerly directions most of the time. One map shows probabilities for a fall of $1 \mathrm{~cm}$ (about $0.5 \mathrm{in}$ ) or greater and the other for a fall of $10 \mathrm{~cm}$ (about 4 in) or greater. Northern Skamania County has an annual probability of a tephra fall of $10 \mathrm{~cm}$ or more of about 1 in $100(1 \%)$ to 1 in $500(0.2 \%)$. A much larger area, including most of Skamania, Klickitat, and Yakima counties and the Yakima Indian Reservation, has a similar probability of a tephra fall of $1 \mathrm{~cm}$ or more. In fact, the maps 
Table 1. Summary of eruption rates and coverage by lava flows that determine lava-flow hazard zones in Mount Adams region [ -- designates no available data]

\begin{tabular}{|c|c|c|c|c|c|c|c|}
\hline $\begin{array}{l}\text { Volcanic field } \\
\text { or location }\end{array}$ & $\begin{array}{l}\text { Area } \\
\left(\mathrm{km}^{2}\right)\end{array}$ & $\begin{array}{l}\text { Eruption rate } \\
\qquad \mathrm{km}^{3} \text { per } \\
10,000 \mathrm{yr})\end{array}$ & $\begin{array}{l}\text { Average } \\
\text { burial rate } \\
\text { (m per } \\
10,000 \mathrm{yr} \text { ) }\end{array}$ & $\begin{array}{l}\text { Number of } \\
\text { eruptions }\end{array}$ & $\begin{array}{l}\text { Area } \\
\text { covered by } \\
\text { lava flows } \\
\left(\mathrm{km}^{2}\right)\end{array}$ & $\begin{array}{l}\text { Percent of } \\
\text { area } \\
\text { covered }\end{array}$ & $\begin{array}{c}\text { Lava-flow } \\
\text { hazard } \\
\text { zone }\end{array}$ \\
\hline \multicolumn{8}{|c|}{ Mount Adams volcanic field } \\
\hline Focal Area & & & & & & & LA \\
\hline Past $100,000 \mathrm{yr}$ & 800 & 5.1 & 6.5 & -- & 370 & 46 & \\
\hline \multicolumn{4}{|c|}{ North and South Ends and Inliers } & & & & LB \\
\hline Past $10,000 \mathrm{yr}$ & 550 & -- & -- & 0 & 0 & 0 & \\
\hline Past $10,000 \mathrm{yr}$ & 1000 & 0.1 & 0.10 & 1 & 51.2 & 5 & \\
\hline Past 1 million yr & 1000 & 0.2 & 0.22 & -- & -- & -- & \\
\hline \multicolumn{4}{|c|}{ Scattered vents around fields } & & & & $\mathbf{L C}$ \\
\hline Past $10,000 \mathrm{yr}$ & 4100 & 0.2 & 0.05 & 2 & 9.0 & 0.2 & \\
\hline \multicolumn{8}{|c|}{ Vancouver to Wind River } \\
\hline Past 1 million yr & 1600 & 0.1 & 0.04 & -- & -- & -- & \\
\hline \multicolumn{4}{|c|}{ Simcoe Mountains volcanic field } & & & & LC \\
\hline Past 1 million yr & 400 & -- & -- & 25 & -- & -- & \\
\hline Past $100,000 \mathrm{yr}$ & 400 & -- & -- & 0 & 0 & 0 & \\
\hline
\end{tabular}

demonstrate that even though Mount Adams is a meager tephra producer, the region around Mount Adams has the highest probability of tephra fall of anywhere in the western conterminous United States, owing to its location just downwind of Mount St. Helens!

\section{HOW LARGE AN ERUPTION IS POSSIBLE AT MOUNT ADAMS?}

The maximum credible eruption at Mount Adams is an event of very low annual probability -- on the order of less than 1 in 100,000 -- but one that would have very serious consequences. Although preparing for an event of such low probability is problematic, we should nonetheless understand the worst-case scenario.
Two types of large-scale eruptions occur at volcanoes like Mount Adams. Caldera-forming eruptions are the type that created Crater Lake, Oregon, about 7,600 years ago. During this eruption, $50 \mathrm{~km}^{3}(12$ $\mathrm{mi}^{3}$ ) of magma erupted explosively. Tephra fell from western Oregon to British Columbia, Alberta, and Wyoming. Pyroclastic flows swept out 30 to $60 \mathrm{~km}$ (20 to $40 \mathrm{mi}$ ) from the volcano. Fortunately, recent studies of the Mount Adams system conclude that conditions there are not conducive to such an eruption. Another type of eruption that is possible at Mount Adams is one like the 1980 eruption of Mount St. Helens -- specifically the large lateral blast that devastated more than $500 \mathrm{~km}^{2}\left(200 \mathrm{mi}^{2}\right)$ north of the volcano. Were it to occur at Mount Adams, a lateral blast of similar size and mobility could engulf a broad sector of the hazard zone outlined on plate 1 . The irregular shape of the hazard zone reflects the topogra- 

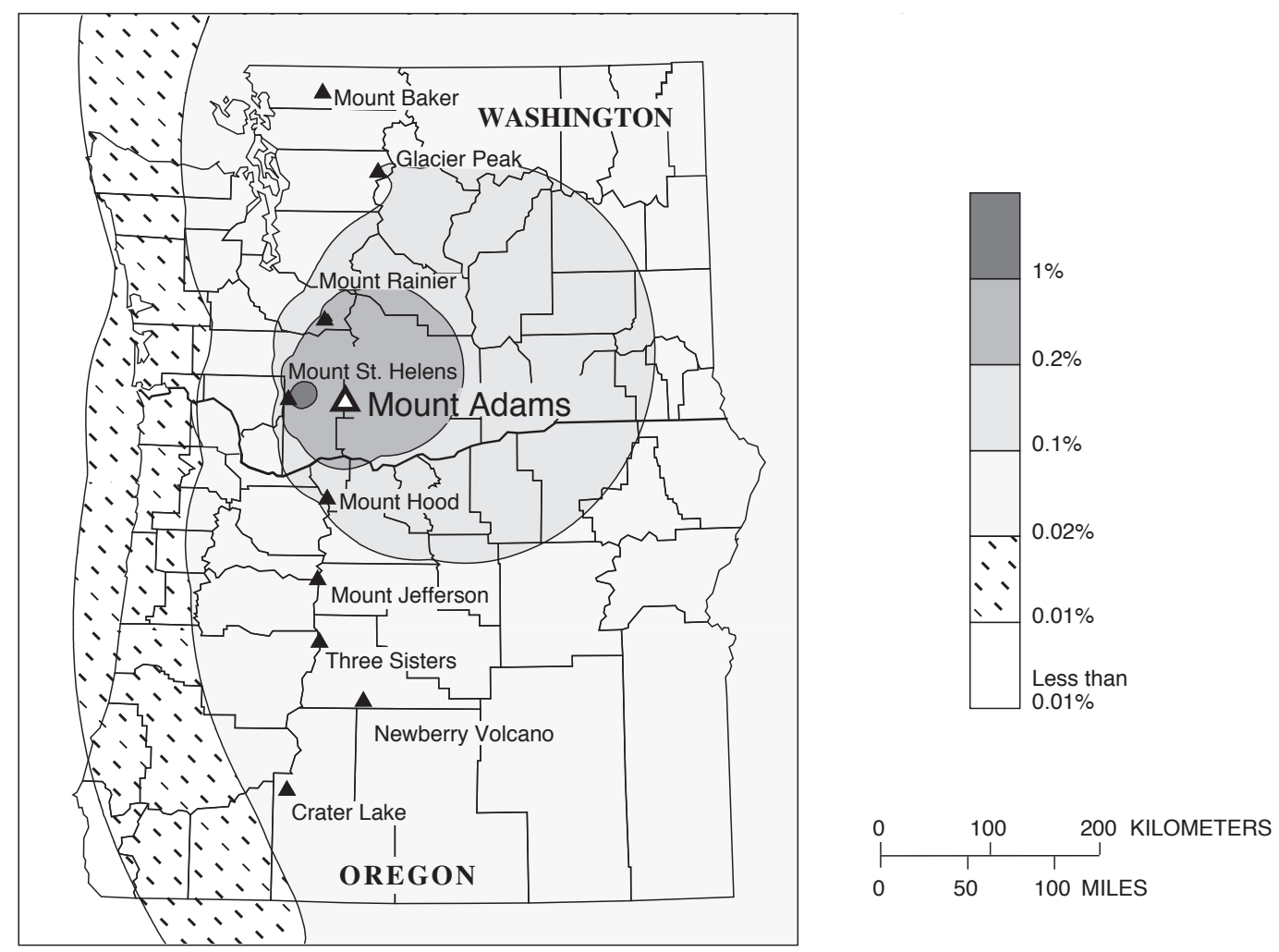

Figure 2a. Annual probablility of $1 \mathrm{~cm}$ or more of tephra accumulation in Washington and Oregon from major Cascade volcanoes.
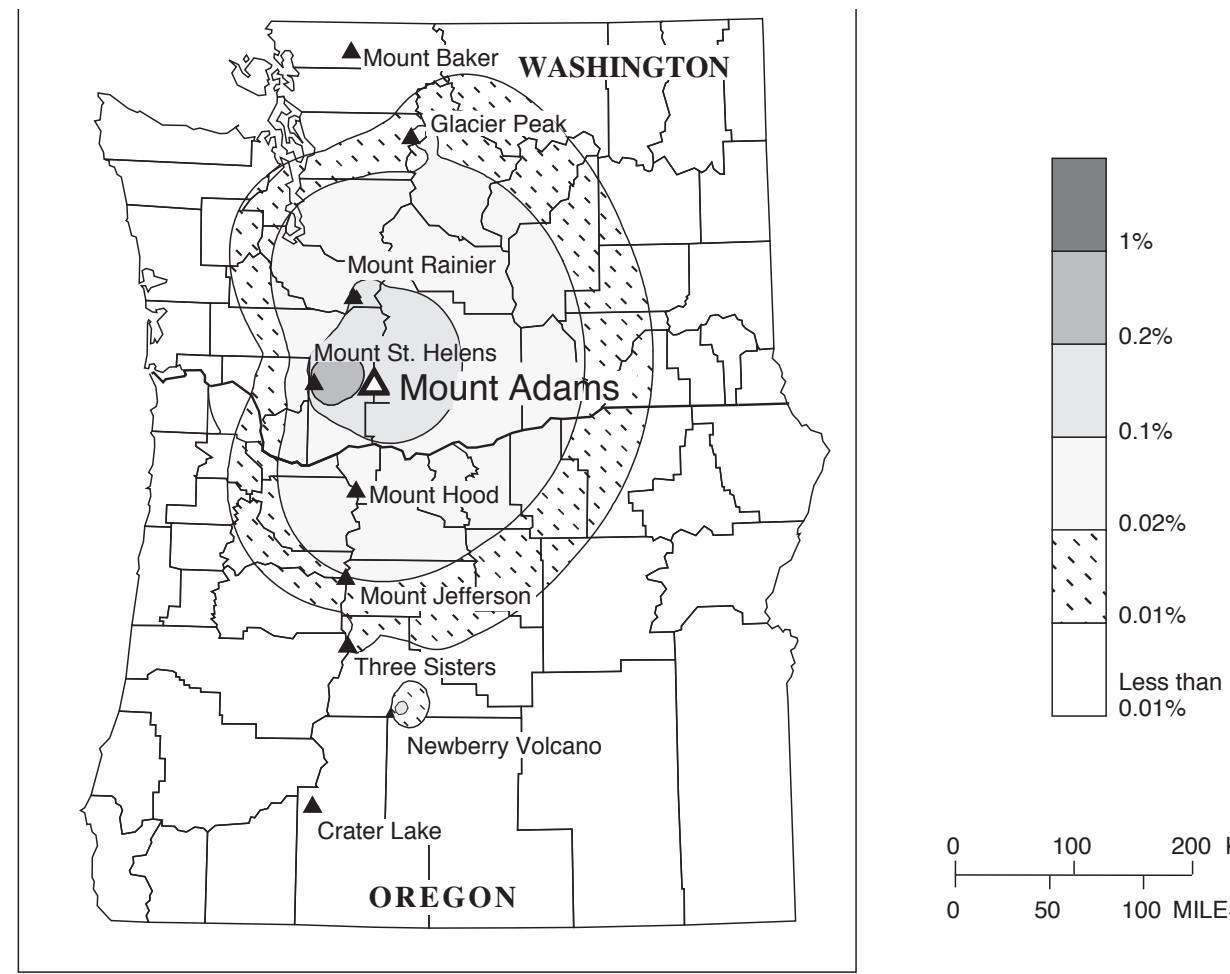

Figure 2b. Annual probability of $10 \mathrm{~cm}$ or more of tephra accumulation in Washington and Oregon from major Cascade volcanoes. 
phy of the surrounding area. The zone extends farthest from the volcano where elevations drop most steeply.

\section{HAZARD FORECASTS AND WARNINGS}

Scientists recognize several signs of impending volcanic eruptions. The upward movement of magma, or molten rock, into a volcano prior to an eruption causes changes that can be detected by geophysical measurements and visual observation.

Swarms of small earthquakes are generated as rocks break to make room for rising magma or as heating of fluids causes underground pressures to increase. Heat from the magma can increase the temperature of ground water and boost temperatures and steaming from fumaroles, which are vents that emit volcanic gas; it can also generate small steam explosions. The composition of gases emitted by fumaroles can change as magma nears the surface. Injection of magma into the volcano can cause swelling or other types of surface deformation.

The regional seismic network operated jointly by the U.S. Geological Survey and the Geophysics Program at the University of Washington can detect earthquakes around Mount Adams. Currently, the Mount Adams region has very few small earthquakes compared to Mounts St. Helens, Rainier, and Hood. Thus an increase in the level of earthquake activity at Mount Adams would be noticed quickly. At monitored volcanoes similar to Mount Adams, a notable increase in seismicity typically has occurred days to months before the onset of eruptions.

Owing to Mount Adams' low level of eruptive activity in the recent geologic past, scientists have not deployed instruments to detect other types of precursory activity at the volcano. But an increase in seismicity would prompt the deployment of appropriate monitoring systems. Such a response would be conducted by scientists from the U.S. Geological Survey and other institutions.

Periods of unrest at volcanoes are usually times of great uncertainty. Although outstanding advances have been made in volcano monitoring and eruption forecasting over the past few decades, scientists are often able to make only very general statements about the probability, type, and scale of an impending eruption. Precursory activity can go through accelerating and decelerating phases, and sometimes die out with- out leading to eruption. Government officials and the public must realize the limitations in forecasting eruptions and be prepared for such uncertainty.

Some hazardous events at Mount Adams, including debris avalanches and related lahars, may have little or no advance warning. Onset of earthquakes and deformation related to eruption precursors would, however, increase the probability of debris avalanches, especially those of large size that have the greatest chance of impacting developed and settled areas.

\section{PROTECTING OUR COMMUNITIES AND OURSELVES FROM VOLCANO HAZARDS}

Communities, businesses, and citizens can undertake several actions to mitigate the effects of future eruptions, debris avalanches, and lahars. Long-term mitigation includes using information about volcano hazards when making decisions about land use and siting of critical facilities. Development can avoid areas judged to have an unacceptably high risk. Or developments can be planned to reduce the level of risk, or even institute engineering measures to mitigate risk. For example, a real-estate development along a valley could set aside low-lying areas at greatest risk from lahars for open space or recreation, and use valley walls or high terraces for houses and businesses. In the Mount Adams region, much of the area in hazard zones for eruptive events lies in the Gifford Pinchot National Forest or remote areas of the Yakima Indian Reservation. Areas of greatest concern are located along the channels and flood plains of rivers that are subject to lahars. The relatively low population density in these higher-hazard areas simplifies the often complex economic and social aspects of hazard management. But these conditions also may increase the need for individuals who are at risk to know about volcano hazards and to make informed decisions on their own.

When volcanoes erupt or threaten to erupt, shortterm emergency responses are needed. Such responses will be most effective if citizens and public officials have an understanding of volcano hazards and have planned the actions needed to protect communities. Because the time can be short between onset of precursory activity and an eruption (days to months), and because some hazardous events can occur without warning, suitable emergency plans should be made beforehand. Public officials need to 
consider issues such as public education, communications, and evacuations. Emergency plans already developed for floods may be applicable, with modifications, to hazards from lahars in valleys that head on Mount Adams.

Businesses and individuals should also make plans to deal with volcano emergencies. Planning is prudent because once an emergency begins, public resources can often be overwhelmed, and citizens may need to provide for themselves and make informed decisions. The Red Cross recommends numerous items that should be kept in homes, cars, and businesses for many types of emergencies that are much more probable than a volcanic eruption. Other items that will help include a map showing the closest access to high ground.

The most important additional item is knowledge about volcano hazards and, especially, a plan of action based on the relative safety of areas around home, school, and work. If your house is within a hazard zone for debris avalanches and lahars, a neighbor's house on a nearby hillside may be a good place to go if you learn that a hazardous event may be in progress. If you feel that you should evacuate, be certain that you don't move into a more hazardous area. Be aware of the location of the volcano and valleys that may be swept by lahars. The best strategy for avoiding the path of a lahar is to move to the highest possible ground. A safe height above river channels depends on many factors including size of the lahar, distance from the volcano, and shape of the valley. For areas around and downstream from the Trout Lake lowland, all but the largest lahars will probably rise no more than $50 \mathrm{~m}(160 \mathrm{ft})$ above river level. Once a lahar is flowing down a valley beyond the flanks of the volcano, its speed will likely be less than 50 kilometers per hour (30 miles per hour). Thus if higher ground is not accessible, a second option is to drive downvalley at a reasonable speed.

\section{ADDITIONAL READING}

Hildreth, Wes, and Lanphere, M.A., 1994, Potassium-argon geochronology of a basalt-andesite-dacite arc system: The Mount Adams volcanic field, Cascade Range of southern Washington: Geological Society of America Bulletin, v. 106, p. 1413-1429.

Hildreth, Wes, and Fierstein, Judy, 1995, Geologic map of the Mount Adams volcanic field, Cascade Range of southern Washington: U.S. Geological Survey Miscellaneous Investigations Series Map I-2460.
Scott, K.M., and Vallance, J.W., 1995, Debris flow, debris avalanche, and flood hazards at and downstream from Mount Rainier, Washington: U.S. Geological Survey Hydrologic Investigations Atlas HA-729.

Vallance, J.W., 1994, Postglacial lahars and potential hazards in the White Salmon River system on the southwest flank of Mount Adams, Washington: U.S. Geological Survey Open-File Report 94-440, 51 p. 